\title{
SEROPREVALENCE PATTERNS OF BOVINE BRUCELLOSIS IN ORGANISED AND UNORGANISED FARMS OF COASTAL ANDHRA PRADESH, INDIA
}

\author{
B. DEEPTHI *, R. N. RAMANI PUSHPA, M. SRIVANI \\ K. L. KAVITHA AND K. V. SUBRAMANYAM \\ Department of Veterinary Microbiology \\ NTR College of Veterinary Science, Gannavaram \\ Krishna Dt- 521 102, Andhra Pradesh, India
}

\begin{abstract}
Brucellosis is an economically important infection of livestock and humans due to the reproductive problems it causes and also the risk to the public health. A study of bovine brucellosis was conducted using different serological tests to determine the disease status in an organized dairy farm and two private dairy farms in coastal area of Andhra Pradesh. A total of 445 serum samples from 200 cattle and 245 buffaloes were screened using Rose Bengal plate test (RBPT), Serum agglutination test (SAT), Lateral flow assay (LFA) and Indirect enzyme linked immunosorbent assay (i-ELISA). An overall prevalence of $9.88 \%, 7.78 \%, 6.29 \%$ and $7.86 \%$ was detected by RBPT, SAT, LFA and i-ELISA respectively. The present study identified overall high prevalence of bovine brucellosis in un-organized private farms particularly in female white cattle. RBPT and i-ELISA can be used successfully to declare the disease status of the herd and to implement control programmes like test and culling of the affected animals and adoption of strict hygienic measures in the farm.
\end{abstract}

Key words: Bovine Brucellosis, iELISA, RBPT, SAT, Screening

Brucellosis is a highly contagious, zoonotic and economically important bacterial disease of animals and humans worldwide.
A huge economic loss includes abortions, loss in milk production, low fertility rates and cost of replacement of animals

*Corresponding Author 
(Mc Dermott and Armi, 2002). Farmers, shepherds, milkers, veterinarians and other workers in dairy industry are at risk of infection and manifests as a severe debilitating disease that require prolonged treatment with a combination of antibiotics. True incidence of human brucellosis in India may be 25 times higher than the reported incidence due to misdiagnosis and under reporting (Smits and Kadri, 2005). Hence, effective control and eradication measures should be implemented which can be achieved only by early, reliable and accurate diagnostic procedures and vaccination. Cultural examinations are the gold standard tests but are time consuming, hazardous and not sensitive. Hence, a presumptive diagnosis can be made by a combination of at least two serological tests for accurate diagnosis and maximal specificity (Kaltungo et al., 2014).

This study was designed to assess the prevalence of brucellosis in a selected organized and two private dairy farms in three districts of Andhra Pradesh.

\section{MATERIALS AND METHODS}

A total of 445 bovine sera samples were screened from an organized dairy farm (Buffalo Research Station, SVVU, Tirupati) and two private dairy farms at Visakhapatnam and Nallazarla areas of
Andhra Pradesh, India. Details of the farms were mentioned in Table 1. All the animals in the three farms belonged to different age groups from 6 months to 9 years.

Sera samples were collected using aseptic methods. Approximately $6 \mathrm{~mL}$ of blood was collected from jugular vein using vacutainers (Becton Dickson, UK). The vacutainers were kept in an icepack in slanting position to allow for blood clotting. The samples were immediately transported to the laboratory and the collected blood in the vacutainers was centrifuged at $5000 \mathrm{rpm}$ for 10 minutes to obtain a clear serum and stored at $-20^{\circ} \mathrm{C}$ until analysed. High, low and negative sera of known titers available at Department of Veterinary Microbiology, NTR College of Veterinary Science, Gannavaram were used as controls in all the assays.

Rose Bengal plate test: All the 445 sera samples were subjected to Rose Bengal plate test (RBPT) according to standard protocol (Stemshorn et al., 1985). Rose Bengal antigen was obtained from NIVEDI, Bangalore. Antigen and serum samples at room temperature are mixed in equal volumes (25-30 $\mu \mathrm{L})$, agitated gently and any visible agglutination reaction should be considered positive after the 4 minutes period. 
Seroprevalence of bovine brucellosis in Andhra Pradesh

Table 1. Details and history of the farms for sample collection

\begin{tabular}{|c|c|c|c|c|c|c|}
\hline $\begin{array}{l}\text { Name of the } \\
\text { farm }\end{array}$ & $\begin{array}{c}\text { Total } \\
\text { strength } \\
\text { of the farm }\end{array}$ & Breed & $\begin{array}{c}\text { History } \\
\text { of } \\
\text { abortions }\end{array}$ & $\begin{array}{l}\text { Breeding } \\
\text { history }\end{array}$ & $\begin{array}{c}\text { AI / } \\
\text { Natural } \\
\text { service }\end{array}$ & $\begin{array}{c}\text { Calf hood } \\
\text { vaccination } \\
\text { details }\end{array}$ \\
\hline $\begin{array}{l}\text { Buffalo } \\
\text { Research } \\
\text { Station }\end{array}$ & 95 & $\begin{array}{l}\text { Murrah, } \\
\text { Graded } \\
\text { Murrah }\end{array}$ & Nil & $\begin{array}{l}\text { Long calving } \\
\text { intervals }\end{array}$ & AI & Nil \\
\hline $\begin{array}{l}\text { Private } \\
\text { farm-1 }\end{array}$ & 200 & $\begin{array}{l}\text { Graded } \\
\text { Murrah }\end{array}$ & Present & $\begin{array}{l}\text { Long calving } \\
\text { intervals, } \\
\text { Mastitis, } \\
\text { Metritis }\end{array}$ & AI & Nil \\
\hline $\begin{array}{l}\text { Private } \\
\text { farm }-2\end{array}$ & 150 & $\begin{array}{l}\text { Sahiwal, } \\
\text { Kankrej, } \\
\text { Gir }\end{array}$ & Present & $\begin{array}{l}\text { Long calving } \\
\text { intervals, } \\
\text { Mastitis, } \\
\text { Metritis }\end{array}$ & $\begin{array}{l}\text { Natural } \\
\text { service }\end{array}$ & Nil \\
\hline
\end{tabular}

*Private farms-1\& 2 are located at Visakhapatnam and West Godavari districts respectively

Serum agglutination test: Serum samples positive by RBPT of organized dairy farm were tested by SAT (OIE, 2011) and Brucella plain antigen was obtained from IVRI, Izatnagar, Bareilly, UP. Serum samples were serially diluted from 1:10 to 1:5120, incubated at $37^{\circ} \mathrm{C}$ for $18-24 \mathrm{hrs}$ and titres 1:40 IU or above were considered as positives.

\section{Indirect enzyme linked immunosorbent} assay (i-ELISA): The i-ELISA kit for the detection of antibrucella antibodies was obtained from Genomix Molecular Diagnostics Pvt. Ltd., Hyderabad and the procedure was followed as per the manufacturer's protocol.

A primary dilution of $1 / 100$ of all the test and control sera samples was prepared by adding $2 \mu \mathrm{L}$ of serum to $198 \mu \mathrm{L}$ of sample diluting buffer. $100 \mu \mathrm{L}$ of each serum sample is dispensed into each well of the antigen coated plate. Every sample was tested in duplicate. The plates were covered with aluminium foil and incubated at $37^{\circ} \mathrm{C}$ for one hour. After the incubation period, the plates were washed 4 times with 300 $\mu \mathrm{L}$ wash buffer provided with the kit. The wash buffer residues are removed completely by tapping the plate on a tissue paper. One hundred microlitres $(100 \mu \mathrm{L})$ of the conjugate solution is added into each well and incubated at $37^{\circ} \mathrm{C}$ for one hour. The plates were washed once again 4 times with $300 \mu \mathrm{L}$ wash buffer and tapped on the tissue paper. o-Phenylene diamine dihydrochloride (OPD) solution was freshly prepared $(1 \mathrm{mg} / 1 \mathrm{~mL}$ of PBS) and substrate $\left(\begin{array}{lll}30 \% & \mathrm{H}_{2} \mathrm{O}_{2}\end{array}\right)$ was added just before 
dispensing OPD to the wells. The plate was incubated in dark at room temperature for 10-15 minutes until the colour develops. The reaction was stopped by adding 100 $\mu \mathrm{L}$ of $1 \mathrm{M} \mathrm{H}_{2} \mathrm{SO}_{4}$ provided with the kit and the OD values were read at $492 \mathrm{~nm}$ using Multiskan Go (Thermo -Scientific).

Lateral flow assay (LFA): Lateral flow immune chromatographic assay is a rapid antibody detection test kit obtained from Genomix Molecular Diagnostics Pvt. Ltd., Hyderabad and the procedure was followed as per the manufacturer's protocol.

The testing device was placed on a level surface. $5 \mu \mathrm{L}$ of the sample and 2 drops of sample diluents buffer provided with the kit are placed in the sample well. Appearance of purple coloured band both at the test and control slots indicates positive test.

\section{RESULTS}

A total of 445 sera samples were screened for Brucellosis by RBPT, SAT, LFA and i-ELISA from the organized and private dairy farms in coastal Andhra Pradesh. An overall seroprevalence of $9.88 \%, 7.78 \%$, $6.29 \%$ and $7.86 \%$ was detected by the said tests. In this study prevalence of brucellosis was compared between organized and unorganized farms. This is comprised of, out of 95 buffaloes tested in organized farm, 4 (4.2\%), $2(2.1 \%), 2(2.1 \%)$ and $2(2.1 \%)$ were positive by RBPT, SAT, LFA, and iELISA respectively. A total of 350 sera samples collected from two different private dairy farms revealed $40(11.4 \%)$, $31(8.85 \%), 26(7.4 \%)$ and $33(9.4 \%)$ positive by RBPT, SAT, LFA and i-ELISA respectively (Table 2). Using Chi- square test, prevalence of Brucellosis is compared among different farms and different diagnostic tests and this revealed no heterogeneity.

Table 2. Farm wise prevalence of bovine brucellosis by different serological tests

\begin{tabular}{lcllcc}
\hline \multirow{2}{*}{$\begin{array}{c}\text { Name of the } \\
\text { farm }\end{array}$} & $\begin{array}{c}\text { Herd } \\
\text { size }\end{array}$ & RBPT & SAT & LFA & iELISA \\
\cline { 3 - 6 } & & & & & \\
\hline Buffalo & 95 & $4(4.2 \%)$ & $2(2.1 \%)$ & $2(2.1 \%)$ & $2(2.1 \%)$ \\
Research & & & & & \\
Station & & & & & \\
Pvt. farm-1 & 200 & $27(13.5 \%)$ & $20(10 \%)$ & $17(8.5 \%)$ & $22(11.0 \%)$ \\
Pvt. farm-2 & 150 & $13(8.6 \%)$ & $11(7.33 \%)$ & $9(6.0 \%)$ & $11(7.3 \%)$ \\
\hline & 445 & $44(9.88 \%)$ & $33(7.41 \%)$ & $28(6.29 \%)$ & $35(7.86 \%)$ \\
\hline
\end{tabular}

The Chi-square statistic is 5.1846. The $\mathrm{p}$ - value is 0.158771 . The result is not significant at $\mathrm{p}<0.01$ 


\section{DISCUSSION}

On farm comparison basis, our study revealed high prevalence in un-organized farms compared to organized farms which may be due to unhygienic practices in disposing aborted fetus, placenta, vaginal discharges, contaminated pastures, insufficient floor space per animal, lack of periodical screening and trained personnel. This finding is in agreement with Singh et al. (2004) who reported low prevalence in organized farms $(5.2 \%)$ when compared to unorganized poorly managed farms (14.81\%). Naeem et al. (1990) also reported higher prevalence of bovine brucellosis in privately owned animals.

Seroprevalence was high in female animals (44/409) as compared to male animals (0/ 36). These findings were in accordance to Vaishali et al. (2005), Kubuafor et al. (2000) and Shome et al. (2014). High prevalence in female population may be due to introduction of unscreened female animals into the herd. Junaidu et al. (2008) also stated that the foci of infection remain in female which might be the cause of high prevalence rates in female population.

Species and breed wise prevalence revealed higher incidence in cattle than in buffaloes. Of the total 445 animals tested, 245 were graded Murrah buffaloes and 200 were cattle, belonging to Kankrej, Gir and Sahiwal breeds. Among 245 buffaloes tested 17 (6.93\%), 12 (4.89\%), 11 (4.48\%) and $13(5.3 \%)$ were positive by RBPT, SAT, LFA and i-ELISA respectively whereas among 200 cattle, 27 (13.5\%), 21 $(10.5 \%), 17(8.5 \%)$ and $22(11 \%)$ were positive by RBPT, SAT, LFA and i-ELISA respectively. Higher disease prevalence in cattle in comparison to buffaloes has been reported by other researchers (Abbas and Aldeewan, 2009; Shafee et al., 2011; Ramesh et al., 2013). In this study higher prevalence in cattle might be due to the large size of the herd, extensive movement of animals and mingling with other herds at common grazing and water points in private unorganized dairy farms.

The present study identified overall high prevalence of bovine brucellosis in unorganized private farms particularly in female Kankrej cattle. In the organized dairy farm under study, among the four positive animals, 3 were adult female animals and 1 was a calf born to one of the positive female animal. The positive adult animal had no history of abortion but has a long calving interval. The calf was healthy and had no obvious clinical signs. Sexually immature calves which acquired infection remain infected for life (Madkour, 2001). This indicates that the infected calf would be a potential source of infection to other 
animals in the herd. In contrast, Ray et al. (1988) could not isolate Brucellae from progeny of infected cows indicating that latency may be infrequent.

Overall seroprevalence rates were 9.88\%, $7.41 \%, 6.29 \%$ and $7.86 \%$ by RBPT, SAT, LFA and iELISA respectively. All serum samples were subjected to RBPT and LFA for screening and to SAT and iELISA for confirmation. In our study, however $20.4 \%$ of the positive samples in RBPT could not be confirmed by iELISA. A possible explanation for this disagreement between RBPT and iELISA could be that the cross reactions with other bacteria could have led to false positive reactions and the temperature of the antigen and sera used at the ambient temperature at which the test was conducted also influences the sensitivity and specificity of the test (Alton, 1981; Macmillan et al., 1990). However the LFA test conducted in the study is a less sensitive test and could not detect $36.3 \%$ of RBPT and $20 \%$ of iELISA positive samples. Hence, LFA could not be recommended as a general screening test. The SAT also detects IgG less effectively especially IgG1 resulting in low assay

\section{REFERENCES}

Abbas BA and Aldeewan AB, 2009. Occurrence and epidemiology of specificity which is evident in the present study. Therefore, SAT is generally not used as a single test but in combination with other tests.

As there is no heterogeneity among different farms and different tests used in the present study as shown by Chi- square test, it shows uniform prevalence of the disease irrespective of the farm selected. The result of the present study indicated that brucellosis is endemic in bovines in the studied areas of coastal districts of Andhra Pradesh, India. Higher seroprevalence was recorded in unorganized farms when compared to organized farms where irregular screening of the herd and introduction of unscreened animals into the herd were found to be the main culprits.

\section{ACKNOWLEDGEMENTS}

The authors are thankful to the Associate Dean, NTR College of Veterinary Science, Gannavaram, Krishna Dt, Andhra Pradesh for providing necessary facilities for conducting this study. The present study has been carried out at Department of Veterinary Microbiology, NTR College of Veterinary Science, Gannavaram.
Brucella spps. in raw milk samples at Basrah Province, Iraq Bulg J Vet Med, 12(2): 136-142 
Alton GG, 1981. The control of bovine brucellosis: Recent developments. World Anim Rev (FAO), 39: 17-24

Junaidu AU, Oboegbule SI and Salihu MD, 2008. Seroprevalence of Brucellosis in prison farm in Sokoto, Nigeria. Asian J Epidemiol, 1(1): 24-28

Kaltungo BY, Saidu SNA, Sackey AKB and Kazeem HM, 2014. A review on diagnostic techniques for Brucellosis. African J Biotechnol, 13(1): 1-10

Kubuafor DK, Awumbila B and Akarimori BD, 2000. Seroprevalence of brucellosis in cattle and humans in the Akwapim South district of Ghana: Public Health implications. Acta Tropica, 76(1) : 45-48

Madkour MM (2001). Madkour's Brucellosis, 2nd Edn., Springer, London

Mc Dermott JJ and Arimi SM, 2002. Brucellosis in sub- Saharan Africa: epidemiology, control and impact. Vet Microbiol, 90(1-4): 111-134

Macmillan AP, Greiser-Wilke I, Moennig V and Mathias LA, 1990. A competition enzyme immunoassay for brucellosis diagnosis. Dtsch Tierarztl Wochenschr, 97: 83-85

Naeem K, Akhta S and Ullah N, 1990. The serological survey of bovine brucellosis in Rawalpindi and Islamabad. The Pak Vet J, 10(4): 154156
OIE, 2011. Bovine brucellosis in manual of diagnostic tests and vaccines for terrestrial animals. World Organization for Animal Health, Paris, France, pp135

Ramesh VJ, Rajesh R, Karthik K and Somvanshi R, 2013. Seroprevalence studies of bovine brucellosis using indirect Enzyme linked immunosorbent assay (i-ELISA) at organized and unorganized farms in three different states of India. Vet World, 6(8): 550-553

Ray WC, Brown RR, Stringfellow DA, Schnurrenberger PR and Swann AI, 1988. Bovine brucellosis: an investigation of latency in progeny of culture-positive cows. J Am Vet Med Ass, 192(2): 182-186

Shafee M, Rabbani M, Sheikh AA, Ahmed Md and Razzaq A, 2011. Prevalence of bovine brucellosis in organized dairy farms using milk ELISA, in Quetta city, Balochistan, Pakistan. Vet Med Int: doi: $10.4061 / 2011 / 358950$

Shome R, Padmashree BS, Krithiga N, Triveni $\mathrm{K}$ and Sahay $\mathrm{S}$ et al., 2014. Bovine Brucellosis in Organized Farms of India - An Assessment of Diagnostic Assays and Risk Factors. Adv Anim Vet Sci, 2 (10): 557-564

Singh G, Sharma DR and Dhand NK, 2004. Seroprevalence of bovine brucellosis in Punjab. Ind Vet J, 81: 620-623 
Smits HL and Kadri SM, 2005. Brucellosis in India: a deceptive infectious disease. Ind J Med Res, 122: 375-384

Stemshorn BW, Forbes LB, Eaglesome MD, Nielsen KH and Robertson FJ et al., 1985. A comparison of standard serological tests for the diagnosis of bovine brucellosis in Canada. Can $\mathbf{J}$ Comp Med, 49(4): 391-394

Vaishali M, Mahesh K and Tanuj A, 2005. Sero-epidemiological pattern of brucellosis among livestock of district Udhamsingh nagar in Uttaranchal. Indian J Vet Med, 25(1): 28-32 